\title{
Acute appendicitis in an incarcerated crural hernia: analysis of our experience
}

\author{
P. Priego, E. Lobo, I. Moreno, S. Sánchez-Picot, M. A. Gil Olarte, N. Alonso and V. Fresneda \\ Department of General Digestive Surgery. Hospital Ramón y Cajal. Madrid, Spain
}

\begin{abstract}
Introduction: the finding of the vermiform appendix within a crural hernia (Amyand's hernia) is a rare entity whose incidence is not described in the literature.

Objective: the aim of this study was to report our hospital's experience in this kind of pathology.

Material and methods: between 1993 and 2004, 4,572 acute appendicitis and 372 incarcerated crural hernia cases have been operated on in our hospital.

We studied 6 cases of incarcerated crural hernia with vermiform appendix inside. We analyzed in retrospect the following parameters: age, sex, personal history, clinical manifestations, preoperative diagnosis, surgical technique, mean hospital stay, and outcome.
\end{abstract}

Results: all patients were women with a mean age of 78.8 years. Most frequent clinical manifestations included pain and a mass in the right inguinocrural region, of variable intensity and duration.

No clinical, laboratory, or radiographic signs help in reaching a correct preoperative diagnosis.

General anesthesia and a crural approach are used in most surgical operations.

In all cases an appendectomy was performed via the hernia sac, thus proving the presence of acute appendicitis in four of them (66.67\%). A prosthetic mesh was used in 3 cases, and one case of wound infection was found. In the other cases we sutured the hernia ring using prolene.

Conclusion: the finding of the appendix in an incarcerated crural hernia is a rare entity in old women that is difficult to diagnose preoperatively.

Treatment includes appendectomy and herniorraphy. The use of prosthetic mesh is controversial.

Key words: Amyand's hernia. Incarcerated crural hernia. Appendectomy.

Recibido: 09-03-05

Aceptado: 20-05-05.

Correspondencia: Pablo Priego Jiménez. C/ Fermín Caballero, 26, $1^{\circ}$-A. 16004 Cuenca. e-mail: papriego@ hotmail.com
Priego P, Lobo E, Moreno I, Sánchez-Picot S, Gil Olarte MA, Alonso N, Fresneda V. Acute appendicitis in an incarcerated crural hernia: analysis of our experience. Rev Esp Enferm Dig 2005; 97: 707-715.

\section{INTRODUCTION}

The finding of the vermiform appendix, whether inflamed or not, inside a hernia sac is designed in the literature as Amyand's hernia.

However, some authors think that the discovery of the appendix inside a peritoneal sac of an inguinal hernia was first described by De Garangeot in 1731 (1-3).

Claudius Amyand (1681-1740), a French refugee in England because of his Huguenot condition, was the surgeon of George I and George II of England, and one of the founders of St George's Hospital; in 1735 he operated one 11-year-old boy called Havil Handerson, who presented with an inguinoescrotal hernia that was complicated with an stercoraceous fistula. During the operation using a scrotal incision, the appendix -which had been perforated by a pin- was found inside the hernia sac, and the first successful appendectomy in history was carried out (3-8).

According to Deaver (9), Amyand was the first to perform an appendectomy 144 years before the first officially accepted appendectomy by Robert Lawson Tait in 1880 , and 150 years before the first appendectomy performed in the USA by R.J. Hall in 1885 at the Roosevelt Hospital, New York, which incidentally had developed from a strangulated right inguinal hernia.

The finding of the vermiform appendix inside a hernia sac is a rare entity, and has been described in $1 \%$ of all the inguinal hernias. Less common is the finding of an acute appendicitis inside a hernia sac $(3,5,6,8)$. 
The discovery of the appendix inside a crural hernia sac is a variant of Amyand's hernia whose frequency is not described in the literature.

The aim of this study was a literature review for all cases on this subject, and to analyze the experience with this kind of patients in Hospital Ramón y Cajal during the last decade.

\section{MATERIAL AND METHODS}

Between 1993 and 2004, 4,572 acute appendicitis and 372 incarcerated crural hernia cases have been operated on in our hospital.

We included in this study all the patients operated on for incarcerated crural hernia with the vermiform appendix inside the hernia sac.

We excluded all patients operated on for other complicated hernias (e.g.: inguinal, umbilical, obturator,...), and those in which the contents of the hernia sac was not the vermiform appendix (i.e.: intestine, Meckel's diverticu$\operatorname{lum}, \ldots)$.

Six patients fulfilled all requirements, and we retrospectively analyzed the following parameters: age, sex, personal events, clinical presentation, preoperative diagnostic tests, surgical technique, hospital stay, and outcome.

Simultaneously, we performed a literature review about the subject in Medline (keys: Amyand's hernia, incarcerated crural hernia, appendectomy).

\section{RESULTS}

The results obtained from the study are listed in table I.

In this period of time, we operated 4,752 cases of acute appendicitis. In only 6 cases we found the vermiform ap-

Table I. Results

\begin{tabular}{|c|c|c|c|c|c|c|}
\hline & Case 1 & Case 2 & Case 3 & Case 4 & Case 5 & Case 6 \\
\hline Age & 78 & 83 & 75 & 75 & 82 & 80 \\
\hline Sex & Female & Female & Female & Female & Female & Female \\
\hline Personal events & $\begin{array}{l}\text { HTA } \\
\text { Ankle } \\
\text { osteosynthesis }\end{array}$ & $\begin{array}{l}\text { TIA } \\
\text { Inguinal } \\
\text { herniorraphy }\end{array}$ & $\begin{array}{l}\text { Duodenal ulcer } \\
\text { Hypercholes- } \\
\text { terolemia }\end{array}$ & $\begin{array}{l}\text { Mitral valve } \\
\text { disease with } \\
\text { valve prosthesis }\end{array}$ & None & $\begin{array}{l}\text { HTA, chronic } \\
\text { purpura, IgG } \\
\text { Kappa monoclonal pic, } \\
\text { knee prosthesis, } \\
\text { hysterectomy, } \\
\text { ooforectomy }\end{array}$ \\
\hline Presentation & $\begin{array}{l}\text { Continuous pain in } \\
\text { right flank for } 24 \\
\text { hours, irradiated } \\
\text { to thigh } \\
\text { Fever } \\
\text { Vomits } \\
\text { No intestinal } \\
\text { rhythm alteration }\end{array}$ & $\begin{array}{l}\text { Inguinocrural pain } \\
\text { and mass for } \\
12 \text { hours } \\
\text { No fever } \\
\text { No vomits } \\
\text { No intestinal } \\
\text { rhythm alteration }\end{array}$ & $\begin{array}{l}\text { Right inguinal } \\
\text { pain for two days } \\
\text { No fever } \\
\text { No vomits } \\
\text { No intestinal } \\
\text { rhythm alteration }\end{array}$ & $\begin{array}{l}\text { Right inguinal } \\
\text { pain and mass for } \\
\text { two days } \\
\text { No fever } \\
\text { No vomits } \\
\text { No intestinal } \\
\text { rhythm alteration }\end{array}$ & $\begin{array}{l}\text { Right inguinal pain } \\
\text { for } 5-6 \text { hours } \\
\text { No fever } \\
\text { No vomits } \\
\text { No intestinal rhythm } \\
\text { alteration }\end{array}$ & $\begin{array}{l}\text { Right inguinal pain } \\
\text { and tumefaction for hours, } \\
\text { No fever } \\
\text { No vomits } \\
\text { No intestinal } \\
\text { rhythm alteration }\end{array}$ \\
\hline Physical examination & $\begin{array}{l}\text { Right crural hernia } \\
\text { No peritoneal irritation }\end{array}$ & $\begin{array}{l}\text { Right crural hernia } \\
\text { No peritoneal irritation }\end{array}$ & $\begin{array}{l}\text { Right crural hernia } \\
\text { No peritoneal irritation }\end{array}$ & $\begin{array}{l}\text { Right crural hernia } \\
\text { No peritoneal irritation }\end{array}$ & $\begin{array}{l}\text { Right crural hernia } \\
\text { No peritoneal irritation }\end{array}$ & $\begin{array}{l}\text { Right crural hernia } \\
\text { No peritoneal irritation }\end{array}$ \\
\hline Lab tests & Normal & Normal & Normal & Normal & Normal & Normal \\
\hline Radiology & $\begin{array}{l}\text { No intestinal obstruc- } \\
\text { tion signs }\end{array}$ & $\begin{array}{l}\text { No intestinal obstruc- } \\
\text { tion signs }\end{array}$ & $\begin{array}{l}\text { No intestinal obstruc- } \\
\text { tion signs }\end{array}$ & $\begin{array}{l}\text { No intestinal obstruc- } \\
\text { tion signs }\end{array}$ & $\begin{array}{l}\text { No intestinal obstruc- } \\
\text { tion signs }\end{array}$ & $\begin{array}{l}\text { No intestinal obstruc- } \\
\text { tion signs }\end{array}$ \\
\hline Anesthesia & General & Local + sedation & General & General & General & Spinal \\
\hline Approach & Crural & Inguinal & Crural & $\begin{array}{l}\text { Crural with vertical } \\
\text { prolongation }\end{array}$ & Crural & Inguinal \\
\hline Appendectomy? & Yes & Yes & Yes & Yes & Yes & Yes \\
\hline Prosthetic material & Yes & No & Yes & No & No & Yes \\
\hline A. pathology & Acute appendicitis & Acute appendicitis & Acute appendicitis & Acute appendicitis & Normal appendix & Normal appendix \\
\hline Hospital stay (days) & 3 & 3 & 3 & 0 & 0 & 4 \\
\hline $\begin{array}{l}\text { Postoperative } \\
\text { complications }\end{array}$ & $\begin{array}{l}\text { Surgery wound } \\
\text { infection }\end{array}$ & None & None & None & None & None \\
\hline
\end{tabular}


pendix inside a crural hernia sac. This represents an incidence of $0.126 \%$.

Similarly, 372 patients were operated on during this period for incarcerated crural hernia, and in six of them we found the vermiform appendix inside. This represents an incidence of $1.61 \%$.

The six patients were women $(100 \%)$, with a median age of 78.83 years (range $75-83$ years).

According to age, all patients had a moderate-to-severe associated condition (Table I).

First we shall discuss symptom onset: all patients report pain and a mass in the right inguino-crural region $(100 \%)$, which varies in time. In only one case we found fever and vomits (16.67\%), and no patient had symptoms regarding intestinal rhythm changes.

At physical examination all patients (100\%) had a soft, depressible abdomen without peritoneal irritation, and we could feel a hard, tender, non-reducible mass in the right crural region.

Laboratory and radiographic studies were normal $(100 \%)$. In no cases was leukocytosis, biochemical and coagulation changes, or intestinal obstruction signs seen.

Acute appendicitis was diagnosed as associated with crural hernia in all cases, and all patients were operated on with a preoperative diagnosis of incarcerated crural hernia.

In four cases $(66.67 \%)$, surgery was performed under general anesthesia, in one case (16.67\%) under local and sedation anesthesia, and in another case under spinal anesthesia $(16.67 \%)$.

The surgical approach was crural in four cases $(66.67 \%)$, with an extended incision in one case because of technical difficulties; an inguinal approach was used for two cases. In any case, all approaches were anterior, and none was preperitoneal.

Appendectomy was carried out via the hernia sac in all cases $(100 \%)$. When the pathological analysis was completed, acute appendicitis was demonstrated in four cases $(66.67 \%)$, while the vermiform appendix was histologically normal in two.

We repaired the hernia ring using prolene in 3 cases (50\%), and using plug and mesh in the rest $(50 \%)$.

Two patients $(33.3 \%)$ were discharged the same day of surgery, three $(50 \%)$ were discharged the third day after surgery, and one (16.67\%) was discharged the fourth day.

Postoperative course was uneventful in five cases $(83.3 \%)$; one case of surgery wound infection was found in one of the patients in whom a prosthetic material had been used.

\section{DISCUSSION}

The finding of the vermiform appendix inside the hernia sac (Amyand's hernia) is a less frequent entity, and it is described in $1 \%$ of all inguinal hernias. Less frequent is the finding of acute appendicitis inside the hernia sac $(3,5,6,8)$.
The relation between acute appendicitis and incarcerated crural hernia is a rare entity whose frequency has not been described in the literature. It is accepted to be more frequent in postmenopausal women and in the right side (2), but cases inside a left crural hernia have been reported (10).

This observation is noted in our series, because 100\% of patients are postmenopausal women, and in all cases the appendix was found inside an incarcerated right crural hernia.

In 1937 Ryan (11) described that in 8,692 cases of acute appendicitis, the appendix was found in 11 cases inside indirect hernia sacs $(0.13 \%)$, and Carey (12) presented 10 cases observed during 9 consecutive years with an incidence of $1.1 \%$.

A review by Weber et al. (13) reported that there have been a total of 60 cases of acute appendicitis in adults in Amyand's hernias from 1959 through 1999.

Rose and Cosgrove (14) reported in 1988, 66 cases described in the literature of crural hernia with inflamed appendix inside.

The results obtained in our series are similar to those presented by these authors. We described 4,752 cases of appendicitis, and in 6 cases the appendix was inside the hernia sac $(0.126 \%)$. Moreover, we described 6 cases of incarcerated crural hernia with the vermiform appendix inside, which represented 1.6\% amongst 372 incarcerated crural hernias operated upon.

Regarding etiopathogenesis, some authors, including Weber $(3,8,12,13)$, raised the question of why the appendix in Amyand's hernia becomes inflamed. Is Amyand's hernia with acute appendicitis an incidental finding, or is there a relationship between incarceration and inflammation?

Most authors, including ourselves, think the most plausible hypothesis was the second quoted, where an ischemic phenomenon may result from compression at the neck of the sac, thus developing a secondary appendicitis.

Abu-Dalu and Urca $(8,15)$ suggest that when the appendix enters the sac it becomes more vulnerable to trauma and is ultimately retained there by adhesions. Successive traumas, contraction of abdominal muscles, and other sudden increases in intraabdominal pressure may cause ischemia, compression of the appendix resulting in further inflammation, bacterial overgrowth, and acute appendicitis.

It seems that typical symptoms are similar to those of acute appendicitis, with initial epigastric pain that becomes later located to the right lower quadrant or the hernia sac $(3,8)$.

Several authors suggest that the pain of strangulated appendicitis tends to be episodic and crampy instead of the constant dull ache usually seen in strangulated bowel $(3,8)$.

In our series, the typical symptoms of appendicitis developed in all our cases, as all reported sudden pain and a 
mass in the right inguinocrural region; however, no data were available to ascertain whether pain was colic or sustained.

In most revised works fever and leukocytosis are inconsistent $(2,3,8)$. In our series, only one case of fever $\left(37.5^{\circ} \mathrm{C}\right)$ developed, and laboratory and radiographic studies were both normal.

Preoperative diagnosis was exceptional. In the review by Weber et al. (12) of sixty cases of acute appendicitis in Amyand's hernia, only in one case was the correct diagnosis reached preoperatively. In our experience, the diagnosis was made preoperatively in no case, and all patients required surgery.

Some authors suggest that the presence of pain and peritoneal irritation signs near an incarcerated hernia may provide a hint on the presence of appendicitis inside the hernia sac $(2,3,5,8)$, and one imaging modality that may help in preoperative diagnosis is abdominal CT. In our series, the physical examination of the abdomen was normal, there were no peritoneal irritation signs, and CT scans were performed in all cases.

The approach to this kind of hernia is controversial; some authors prefer a preperitoneal approach in strangulated hernias, since this way appendectomy is performed in better conditions, and allows treatment of a likely incarcerated loop and draining of potential appendicular abscesses. These authors considered that this approach minimized the risks of wound infection and hernia relapse $(2,3,8)$.

In our case, all patients were approached anteriorly, with the crural approach being most frequent (66.67\%); only in one case the incision had to be extended to perform the appendectomy under the best conditions.

One question we devised to review the literature was, what do we have to do if the appendix inside the hernia sac does not exhibit macroscopic inflammation?

Franko et al. (2002) suggested that the presence of a normal appendix does not call for appendectomy.

In our opinion, we consider that even when the appendix has no gross inflammation signs, appendectomy should be performed in all cases, since surgery is not more complicated and, even in the absence of macroscopic inflammation, the presence of microscopic inflammation from compression and ischemia within the hernia neck cannot be ruled out.

In our series two cases (33.3\%) had a normal appendix after the pathological analysis, and in none did appendectomy generate any complications.

Under normal conditions, the treatment of Amyand's hernia is appendectomy and emergency herniorraphy $(2,3,5,7,8)$. Most authors point out that appendectomy may be performed via the open hernia sac, but should technical difficulties arise or the appendix is perforated with a periappendicular abscess, there is the possibility that other surgery approaches had to be used.

In our experience, appendicectomy could be performed in all cases via the hernia sac, and only in one case we had to extend the original incision.
To sum it up, many authors agree that prosthetic materials should not be used in contaminated defects of the abdominal wall $(2,3,5,8)$, since this would prevent wound infection and chronic sepsis of the mesh, which lead to a subsequent removal, and the risk of appendicular fistula. In our series, of all six cases, we used prosthetic mesh in three patients, while the others received prolene. In one of them we had one surgery wound infection, which appeared one week after surgery and cured without complications. Other authors such as Armengol Carrasco et al. (7) have also used prosthetic material in the repair of other case of crural hernia with appendix inside and have noticed no postoperative events. Because of these reasons, the use of prosthetic material is still controversial, even if, in our short experience, it has not led to mesh rejection or contamination.

\section{CONCLUSION}

The finding of an inflamed vermiform appendix inside an incarcerated crural hernia is a rare condition, and virtually is never diagnosed before surgery. It is more frequent in postmenopausal women and in the right side. We found no clinical, physical, laboratory or radiographic parameters to help us diagnose this condition preoperatively; we should have it in mind as a differential diagnosis for patients with strangulated crural hernia. General anesthesia was most commonly used, and the approach has to be the same as for a crural hernia. Treatment includes appendectomy (via the hernia sac) and herniorraphy. The use of prosthetic material is controversial, but most authors plead against it because of a higher risk of surgery wound infection.

\section{REFERENCES}

1. El Khatib CM. Strangulated femoral hernia containing acute gangrenous appendicitis: case report and review of the literature. Can J Surg 1987; 30: 50.

2. O El Mansari, F Sakit, MI Janati. Appendicite aiguë sur hernie crurale. Press Med 2002; 31: 1129-30.

3. Torres Hernández D, Roselló Fina JR, del Campo Abad R, Canals Rabasa PP, Enríquez Weinmann ES. Hernia de Amyand: presentación de un caso y revisión de la literatura. Arch Cir Gen Dig 2003; 22 Sep. Available at: www.cirugest.com.

4. Rodríguez Montes JA. Historias de la cirugía. AstraZeneca, 2003. p. 87-102.

5. Zaragoza Fernández C, Peiró Monzó F, Castaño Conesa S, García Aguado R, García Solbes JM, Sanchis Ruiz R. Apendicitis aguda en una hernia crural estrangulada. Una variante de la hernia de Amyand. Rev Esp Enferm Dig 2002; 94 (4): 226-32.

6. Franko J, Sulkowki R. A rare variation of Amyand's Hernia. Am J Gastroenterol 2002; 97 (10): 2684-5.

7. Armengol Carrasco M, Sánchez García JL, Maristany Bienert C, Espín Basany E, López Cano M, Sainz Villacampa B, et al. Hernia de Amyand. A propósito de la primera apendicectomía. Cir Esp 2001; 69: 92.

8. Logan MTBS, Nottingham JM. Amyand's hernia: a case report of an incarcerated and perforated appendix within an inguinal hernia and review of the literature. Am Surg 2001; 67 (7): 628-9. 
9. Deaver JB. Appendicitis. Filadelfia: P. Blakiston's \& Co., 1905.

10. Scepi M, Richer JP, Muller J. Appendice en situation herniarie crurale gauche: à propos d'un cas. Explication par l'Ontogenèse Humaine. J Chir 1993; 130 (11): 479-82.

11. Ryan WJ. Hernia of the vermiform appendix. Ann Surg 1937; 106: 135-9.

12. Carey LC. Acute appendicitis ocurring in hernias: a report of $10 \mathrm{ca}-$ ses. Surgery 1967; 61: 236-8.

13. Weber RV, Hunt ZC, Kral JC. Amyand's hernia. Etiologic and therapeutic implications of two complications. Surg Rounds 1999; 22: 552-6.

14. Rose RH, Cosgrove JM. Perforated appendix in the incarcerated femoral hernia. A place for preperitoneal repair. N Y State J Med 1988: 600-2.

15. Abu-Dalu J, Urca I. Incarcerated inguinal hernia with a perforated appendix and periappendicular abscess. Dis Colon Rectum 1972; 15: 464-5.

16. Capdevilla-Torra J, Sierra Gil E. Retrograde strangulation of the appendix in crural hernia. Rev Esp Enferm Dig 1972; 37 (4): 473-84.

17. Voight AJ, Macfarlane, Estrade RL. Ruptured appendicitis in femoral hernias. Report of two cases and review of the literature. Ann Surg 1974; 179: 24-6.

18. Amyand C. Of a inguinal rupture, with a pin in the appendix caeci incrusted with stone, and some observations on wounds in the guts. Phil Trans R Soc Lond 1736; 39: 329-42. 